\title{
Cardiovascular risks and socioeconomic status: differences between men and women in Finland
}

\author{
Riitta Luoto, Juha Pekkanen, Antti Uutela, Jaakko Tuomilehto
}

\begin{abstract}
Study objective - The study aimed to assess the association of different indicators of socioeconomic status with levels of cardiovascular disease risk factors in men and women aged $25-64$ years.

Design - This was a cross sectional survey, using a community based random sample.

Setting - The provinces of North Karelia and Kuopio in eastern Finland and the cities of Turku and Loimaa and surrounding communities in southwestern Finland in 1987.

Participants - Altogether 2164 men and 2182 women aged $25-64$ years took part. Measurements and main results - Data were collected using self administered questionnaires and the measurement of height, body weight, and blood pressure and blood sampling for lipid determinations were done at the survey site. The risk of cardiovascular disease was determined by calculating a simple risk factor score based on the observed values of HDL and total cholesterol, leisure time, physical activity, blood pressure, medication for hypertension, body mass index, and smoking. Indicators of socioeconomic position used were years of education, family income, marital status, and the person's occupation. Lower levels of education, occupation, and income were all significantly associated with an unfavorable risk factor profile in men and women. Education and occupation showed the strongest associations with the risk factor score in both men and women. The results changed little when adjusting for income and marital status. Family income was more strongly associated with the risk factor score in women than men. When adjusting for occupation and education, income was no longer significantly associated with the risk factor score in men. Marital status was not significantly associated with the risk factor score in either sex.

Conclusions - Using the strength of the association with the cardiovascular risk factor score as the criterion for a good socioeconomic indicator, the present study suggests that education and occupation may be equally good indicators in both men and women. Family income may have some additional importance, especially in women.
\end{abstract}

( $($ Epidemiol Community Health 1994;48:348-354)
Social class is an important variable in epidemiological studies. Between the years 1982 and 1985 , approximately $40 \%$ of 76 studies on chronic diseases published in the American fournal of Epidemiology included some indicator of social class. ${ }^{1}$ In epidemiological studies social class is most often used as a potential confounding factor, but it can also be a risk factor or a risk variable describing the study sample. ${ }^{1}$

Socioeconomic differences in cardiovascular morbidity and mortality can be found in Finland as well as in other countries. ${ }^{2-11}$ In Finland, as in other countries, ${ }^{3912-16}$ lower socioeconomic groups have more detrimental cardiovascular risk factor levels, ${ }^{17}$ poorer perceived health, and less clearly formed health behaviour opinions.

Occupation, probably the most widely used indicator of social class, has been criticised because it originates from male oriented classifications and is generally complex. ${ }^{18}$ In some countries, female occupational data are considered too unreliable because a large number of women are housewives. ${ }^{19}$ Women, therefore, have either been excluded from the study, or the husband's occupation has been used if a woman is married, or her level of education has been preferred instead. ${ }^{20}$ Education has been associated with cardiovascular risk factors and morbidity in several studies. ${ }^{121-24}$ It has been suggested that education has a positive effect on health by producing more effective coping skills and a social milieu in which the adoption of positive health behaviour is reinforced. ${ }^{24} \mathrm{In}$ come has been used far less often than occupation and education as an indicator of socioeconomic status.

Thus far, very little work has been done on sex differences in education, income, and marital status, although there are studies that report results for men and women separately. Studies comparing the sexes with regard to the association of socioeconomic indicators with any health indicator do not exist.

This study aimed to examine sex differences in the association of socioeconomic indicators (occupation, education, family income) and marital status with a cardiovascular risk factor score based on data on smoking, HDL and total cholesterol, physical leisure time activity, hypertension, and body mass index among middle aged, married, single, divorced, and widowed Finnish men and women.

\section{Methods}

A random sample of men and women, aged 25 to 64 years, living in either eastern (North Karelia and Kuopio provinces) or southwestern 
Finland (the town of Turku and the town of Loimaa with neighbouring rural communities) was examined in the 1987 FINMONICA survey. ${ }^{25}$ Participation rates were $78 \%$ in men $(n=2650)$ and $82 \%$ in women $(n=2779)$. Only those individuals with complete data on socioeconomic indicators and cardiovascular risk factors (HDL and total cholesterol, hypertension, smoking, body mass index, and leisure time physical activity) were included in the present analysis $(n=4346)$.

A self administered questionnaire was used to gauge socioeconomic background (marital status, family income, years of education) and use of drugs. Blood pressure was measured twice in the right arm of the subject while sitting, after five minutes rest in the sitting position. An average of two measurements was used to reduce intraindividual variability of blood pressure. Also, antihypertensive medication was used to classify the severity of hypertension. Serum total and HDL cholesterol were determined enzymatically, ${ }^{25}$ other fractions were not available. Body mass index was calculated as the ratio of weight (in $\mathrm{kg}$ ) to the height (in $\mathrm{m}^{2}$ ).

Data on the occupation of the study population was obtained through record linkage with the 1985 census of the Finnish population. Women were classified according to their own current or previous occupation if they were or ever had been working (most women, 91\%). Otherwise they were classified according to their husband's occupation. The following definitions of social classes, based on the classification of the Central Statistical Office of Finland ${ }^{26}$ was applied:

(1) Upper white collar workers: upper level employees with administrative, managerial, professional or related occupations.

(2) Lower white collar workers: lower level employees with administrative and clerical occupations, such as supervisors, technicians,

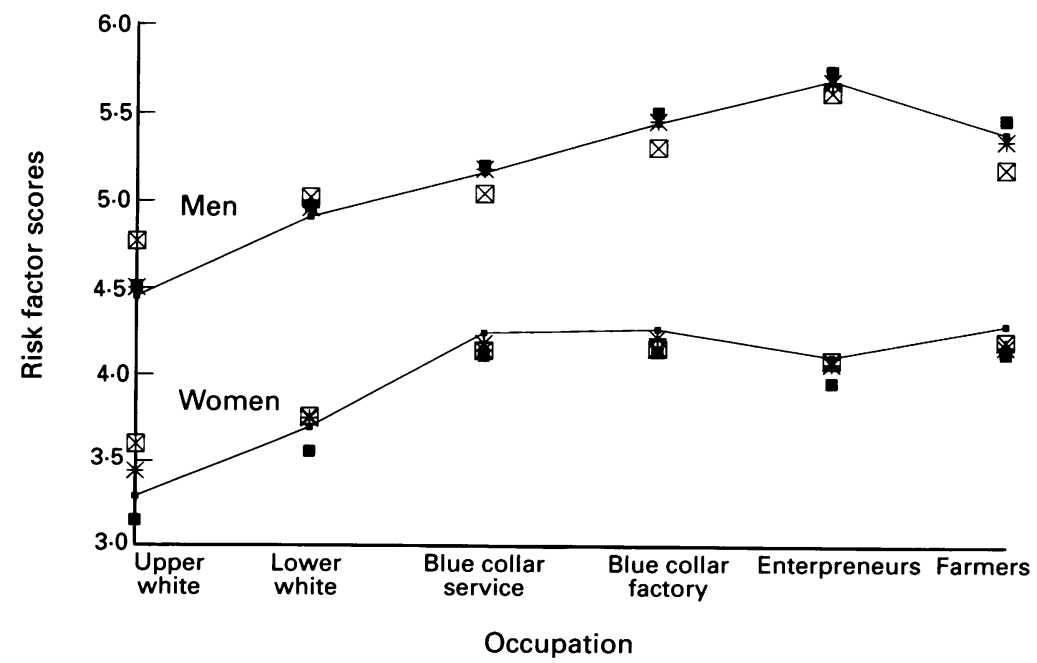

Figure 1 Least squares estimates of risk factor scores in relation to occupation from linear regression models for 2164 men and 2182 Finnish women from a population sample. Estimates from the basic model including age, area, and occupation ( $\mathbf{)}$ ) on the solid line and models adjusted for family income (*), education (囚), or marital status (D) at single points. programmers, clerical workers, sales persons, cashiers, nurses, day-care personnel, lower rank officers.

(3) Blue collar workers (services): blue collar workers employed in distribution and service work, that is, those not working in factories or production.

(4) Blue collar workers (factory): blue collar workers employed in industry or other production work, that is, mining, electricity, gas and water works, and construction.

(5) Entrepreneurs: self employed workers and other employers, excluding farmers.

(6) Farmers: farmers and workers employed in farm and forestry work and in fishing.

Duration of education was divided into four categories: $0-7,8-9,10-12$, and over 13 years. Income was calculated from the reported family income divided by the number of additional adults and the number of children in the family, which were weighted by 0.7 and 0.5 , respectively. Income quartiles per consumption unit were then formed. Socioeconomic indicators were compared with each other by Spearman correlation coefficient in all cases except in comparing occupation and marital status, which were not ordinal variables.

The cardiovascular risk factor score was calculated on the basis of six different risk factors: total and HDL cholesterol, hypertension, smoking, body mass index, and leisure time physical activity. Each risk factor level was divided into three categories, each contributing 0,1 , or 2 points to the risk score. Levels for cholesterol were adapted from the treatment guidelines of the European Atherosclerotic Society, ${ }^{27}$ and for blood pressure and body mass index from WHO guidelines. ${ }^{28}$ Smoking was classified into groups of never smoking, stopped or less than five smoking times/day, and more than five smoking times/day. There was an item on leisure time activity in the form - "How much physical exercise do you get during freetime? If it varies greatly between times of year, mark the alternative, which best describes the overall situation". The multiple choice answers to this question were (1) no leisure time physical activity; (2) walking, bicycling, or other light physical activity at least four hours/week; (3) physical exercise such as jogging, swimming, cross country skiing at least three times/ week; and (4) heavy competitive training several times/week.

Differences in mean levels of risk factor scores in relation to socioeconomic status were estimated by linear regression models using the SAS. ${ }^{29}$ Dummy variables for the socioeconomic indicators were used in the analysis. All results were adjusted for age and area due to geographical differences in risk factor levels. ${ }^{17}$ For example, in figure 1 , the basic model was developed with age, area, and occupation as independent variables. The other three models, marked by separate signs only, are created by adding either education, marital status, or income to the model.

\section{Results}

Half of all participants were from North Kare- 
lia. The distribution of age was equal in both sexes (table 1). The proportion of never married was higher in men than in women. Blue collar factory workers comprised the largest single occupational group in men, whereas almost half of the women studied were lower white collar workers. Women were better educated than men. More women were divorced and there were more widows than widowers (table 1).

Occupation was strongly associated with both education (Spearman correlation coefficients -0.52 men, -0.45 women) and income $(-0.39$ men, -0.37 women $)$ in both men and women. Low education was more common

Table 1 Basic characteristics of the data

\begin{tabular}{|c|c|c|c|c|}
\hline & \multicolumn{2}{|l|}{ Men } & \multicolumn{2}{|c|}{ Women } \\
\hline & No & $(\%)$ & No & $(\%)$ \\
\hline \multicolumn{5}{|l|}{ Age (y): } \\
\hline $25-34$ & 498 & $(23.0)$ & 538 & $(24 \cdot 7)$ \\
\hline $35-44$ & 620 & $(28 \cdot 7)$ & 597 & $(27 \cdot 4)$ \\
\hline $45-54$ & 592 & $(27 \cdot 4)$ & 607 & $(27 \cdot 8)$ \\
\hline $55-64$ & 454 & $(21 \cdot 0)$ & 440 & $(22 \cdot 0)$ \\
\hline \multicolumn{5}{|l|}{ Area: } \\
\hline Northern Karelia & 1043 & $(48 \cdot 2)$ & 1072 & $(49 \cdot 1)$ \\
\hline Southwest Finland & 555 & $(25 \cdot 6)$ & 540 & $(24 \cdot 8)$ \\
\hline Kuopio county & 566 & $(26 \cdot 2)$ & 570 & $(26 \cdot 1)$ \\
\hline \multicolumn{5}{|l|}{ Marital status: } \\
\hline \multicolumn{5}{|l|}{ Married or living } \\
\hline together & 1769 & $(81 \cdot 8)$ & 1716 & $(78 \cdot 6)$ \\
\hline Divorced & 84 & $(3.9)$ & 133 & $(6 \cdot 1)$ \\
\hline Widowed & 24 & $(1 \cdot 1)$ & 106 & $(4.9)$ \\
\hline Never married & 287 & $(13 \cdot 3)$ & 227 & $(10 \cdot 4)$ \\
\hline \multicolumn{5}{|l|}{ Occupational status: } \\
\hline Upper white collar & 284 & $(13 \cdot 1)$ & 243 & $(11 \cdot 1)$ \\
\hline Lower white collar & 425 & $(19 \cdot 6)$ & 1016 & $(46 \cdot 6)$ \\
\hline Blue collar service & 250 & $(11 \cdot 6)$ & 280 & $(12 \cdot 8)$ \\
\hline Blue collar factory & 640 & $(29 \cdot 6)$ & 300 & (13.7) \\
\hline Entrepreneurs & 159 & $(7 \cdot 4)$ & 104 & $(4 \cdot 8)$ \\
\hline Farmers & 406 & $(18 \cdot 8)$ & 239 & (11.0) \\
\hline \multicolumn{5}{|l|}{ Education $(y)$ : } \\
\hline $0-7$ & 490 & $(22 \cdot 6)$ & 357 & $(16 \cdot 4)$ \\
\hline 8-9 & 693 & $(32 \cdot 0)$ & 638 & $(29 \cdot 2)$ \\
\hline $10-12$ & 550 & $(25 \cdot 4)$ & 623 & $(28 \cdot 6)$ \\
\hline $13-$ & 431 & $(19.9)$ & 564 & $(25 \cdot 9)$ \\
\hline \multicolumn{5}{|c|}{ Family income (Finnish marks/y): } \\
\hline-30000 & 484 & $(22 \cdot 4)$ & 515 & $(23 \cdot 6)$ \\
\hline $30-45000$ & 588 & $(27 \cdot 2)$ & 594 & $(27 \cdot 2)$ \\
\hline $45-65000$ & 549 & $(25 \cdot 4)$ & 483 & $(22 \cdot 1)$ \\
\hline 65000 & 543 & $(25 \cdot 1)$ & 590 & $(27 \cdot 0)$ \\
\hline
\end{tabular}

among male entrepreneurs than female entrepreneurs. Male blue collar service workers had a higher family income than women in this group. In upper white collar workers the proportion of women was twice as high as that of men. The association between occupation and marital status was different among men and women. For example, in men, the proportion of married people was highest among upper white collar workers, whereas in women this proportion was highest among farmers' wives (tables 2(A) and (B)).

Risk factor scores were approximately normally distributed in both sexes. Women had lower serum total cholesterol concentrations than men (table 3). HDL cholesterol values differed noticeably between men and women $90 \%$ of women and $60 \%$ of men had an HDL cholesterol concentration over $1.2 \mathrm{mmol} / \mathrm{l}$. Forty per cent of men and $27 \%$ of women had hypertension. Among women there were twice as many never smokers than among men. There were more women than men in the leanest body mass index group. More men than women reported participation in the highest level of leisure time physical activity, which included heavy, competitive physical training or regular activity more than three times per week (table 3).

Overall, socioeconomic indicators explained maximally only $5 \%$ of the total variation in risk factor scores (table 4(A) and (B)). Occupation was significantly associated with the cardiovascular risk factor score in both men and women.

Upper white collar workers had the most favourable risk factor profile, followed by other white collar workers. Occupation had a similar association with the cardiovascular risk factor score in both sexes, and the variance explained by occupation was similar in both sexes (fig 1 , table $4(A)$ and (B)). In both sexes, adding education to the model that included age, area, and occupation increased the variance explained, compared with the basic model (table 4(A) and (B)). Adding income to the

Table 2 Age adjusted frequencies of socioeconomic indicators (\%) by occupation in Finnish men and women aged 25 to 64 in 1987. (Only subjects with information on all socioeconomic indicators included)

\begin{tabular}{|c|c|c|c|c|c|c|c|c|c|c|c|c|c|c|c|c|c|c|c|c|c|c|c|c|c|}
\hline \multirow[b]{2}{*}{ Occupation } & \multicolumn{8}{|c|}{ Length of education (y) } & \multicolumn{8}{|c|}{ Family income ( $F$ mark/y) } & \multicolumn{8}{|c|}{ Marital status } & \multirow[b]{2}{*}{$\begin{array}{l}\text { Total } \\
\text { no }\end{array}$} \\
\hline & $\begin{array}{l}0-7 \\
\%\end{array}$ & $(\mathrm{No})$ & $\begin{array}{l}8-9 \\
\%\end{array}$ & $(\mathrm{No})$ & & -12 & $\begin{array}{l}13- \\
\%\end{array}$ & $(\mathrm{No})$ & $\begin{array}{l}-30 \\
\%\end{array}$ & (No) & $\begin{array}{l}30- \\
\%\end{array}$ & $\begin{array}{r}-45000 \\
(\mathrm{No})\end{array}$ & & $\begin{array}{r}-65000 \\
(\mathrm{No})\end{array}$ & & $(\mathrm{No})$ & & $\begin{array}{l}\text { arried } \\
\text { (No) }\end{array}$ & & $\begin{array}{l}\text { gle } \\
\text { (No) }\end{array}$ & & $\begin{array}{l}\text { orced } \\
\text { (No) }\end{array}$ & & $\begin{array}{l}\text { dowed } \\
(\mathrm{No})\end{array}$ & \\
\hline $\begin{array}{l}\text { (A) Men } \\
\text { Upper white }\end{array}$ & 3 & (9) & 7 & (19) & 17 & $(47)$ & 73 & (209) & 4 & (12) & 11 & $(31)$ & 26 & (76) & 59 & $(165)$ & 91 & $(257)$ & 7 & (19) & 2 & (6) & 1 & (2) & 284 \\
\hline $\begin{array}{l}\text { Lower white } \\
\text { collar }\end{array}$ & 9 & (37) & 25 & (104) & 36 & $(153)$ & 30 & (131) & 9 & (36) & 25 & $(108)$ & 35 & $(150)$ & 31 & (131) & 86 & $(365)$ & 8 & (37) & 4 & $(17)$ & 1 & (6) & 425 \\
\hline $\begin{array}{l}\text { Blue collar - } \\
\text { service }\end{array}$ & 25 & (55) & 40 & (99) & 27 & $(75)$ & 7 & $(21)$ & 19 & $(48)$ & 35 & $(86)$ & 29 & (73) & 17 & $(43)$ & 82 & (201) & 10 & (31) & 7 & (17) & 0 & (1) & 250 \\
\hline $\begin{array}{l}\text { Blue collar - } \\
\text { factory }\end{array}$ & 29 & (157) & 40 & (264) & 26 & $(182)$ & 5 & (37) & 25 & $(155)$ & 32 & (203) & 25 & (167) & 18 & (115) & 80 & (513) & 15 & (96) & 4 & (27) & 1 & (4) & 640 \\
\hline $\begin{array}{l}\text { Entrepreneurs } \\
\text { Farmers }\end{array}$ & $\begin{array}{l}26 \\
38\end{array}$ & $\begin{array}{r}(44) \\
(188)\end{array}$ & $\begin{array}{l}30 \\
42\end{array}$ & $\begin{array}{r}(54) \\
(153)\end{array}$ & $\begin{array}{l}29 \\
15\end{array}$ & $\begin{array}{l}(42) \\
(51)\end{array}$ & $\begin{array}{r}13 \\
5\end{array}$ & $\begin{array}{l}(19) \\
(14)\end{array}$ & $\begin{array}{l}29 \\
44\end{array}$ & $\begin{array}{r}(46) \\
(187)\end{array}$ & $\begin{array}{l}29 \\
27\end{array}$ & $\begin{array}{r}(46) \\
(114)\end{array}$ & $\begin{array}{l}16 \\
16\end{array}$ & $\begin{array}{l}(25) \\
(58)\end{array}$ & $\begin{array}{l}26 \\
13\end{array}$ & $\begin{array}{l}(42) \\
(47)\end{array}$ & 73 & $\begin{array}{l}(132) \\
(301)\end{array}$ & $\begin{array}{l}10 \\
24\end{array}$ & $\begin{array}{l}(15) \\
(89)\end{array}$ & $\begin{array}{l}5 \\
2\end{array}$ & $\begin{array}{l}(9) \\
(8)\end{array}$ & $\begin{array}{l}2 \\
1\end{array}$ & $\begin{array}{l}(3) \\
(8)\end{array}$ & $\begin{array}{l}159 \\
406\end{array}$ \\
\hline $\begin{array}{l}\text { (B) Women } \\
\text { Upper white } \\
\text { collar }\end{array}$ & 0 & (1) & 6 & (14) & 15 & (36) & 78 & (192) & 6 & (15) & 11 & (27) & 21 & $(52)$ & 61 & (149) & 74 & (182) & 17 & (41) & 5 & (12) & 3 & (8) & 243 \\
\hline $\begin{array}{l}\text { Lower white } \\
\text { collar }\end{array}$ & 11 & (84) & 26 & $(242)$ & 37 & $(382)$ & 27 & (308) & 14 & (149) & 27 & (273) & 27 & $(287)$ & 31 & (307) & 77 & (796) & 12 & (126) & 6 & (58) & 5 & (36) & 1016 \\
\hline $\begin{array}{l}\text { Blue collar - } \\
\text { service }\end{array}$ & 27 & (94) & 42 & $(114)$ & 21 & (52) & 9 & (20) & 33 & (93) & 34 & (98) & 19 & $(50)$ & 13 & (39) & 79 & (218) & 6 & (14) & 7 & (20) & 8 & (28) & 280 \\
\hline $\begin{array}{l}\text { Blue collar - } \\
\text { factory }\end{array}$ & 27 & (76) & 43 & $(131)$ & 25 & (78) & 5 & (15) & 32 & (95) & 35 & $(104)$ & 17 & (52) & 16 & (49) & 75 & (225) & 9 & (29) & 10 & (30) & 6 & (16) & 300 \\
\hline $\begin{array}{l}\text { Entrepreneurs } \\
\text { Farmers }\end{array}$ & $\begin{array}{l}16 \\
28\end{array}$ & $\begin{array}{l}(17) \\
(85)\end{array}$ & $\begin{array}{l}38 \\
40\end{array}$ & $\begin{array}{l}(42) \\
(95)\end{array}$ & $\begin{array}{l}28 \\
25\end{array}$ & $\begin{array}{l}(29) \\
(46)\end{array}$ & $\begin{array}{r}17 \\
7\end{array}$ & $\begin{array}{l}(16) \\
(13)\end{array}$ & $\begin{array}{l}33 \\
54\end{array}$ & $\begin{array}{r}(34) \\
(129)\end{array}$ & $\begin{array}{l}32 \\
23\end{array}$ & $\begin{array}{l}(34) \\
(58)\end{array}$ & $\begin{array}{l}13 \\
13\end{array}$ & $\begin{array}{l}(13) \\
(29)\end{array}$ & $\begin{array}{l}22 \\
11\end{array}$ & $\begin{array}{l}(23) \\
(23)\end{array}$ & 88 & $\begin{array}{r}(88) \\
(207)\end{array}$ & $\begin{array}{l}4 \\
6\end{array}$ & $\begin{array}{r}(4) \\
(13)\end{array}$ & $\begin{array}{l}7 \\
2\end{array}$ & $\begin{array}{l}(8) \\
(5)\end{array}$ & $\begin{array}{l}4 \\
4\end{array}$ & $\begin{array}{r}(4) \\
(14)\end{array}$ & $\begin{array}{l}104 \\
239\end{array}$ \\
\hline
\end{tabular}


Table 3 Distribution of the cardiovascular risk factor score in Finnish men and women aged 45-64 in 1987

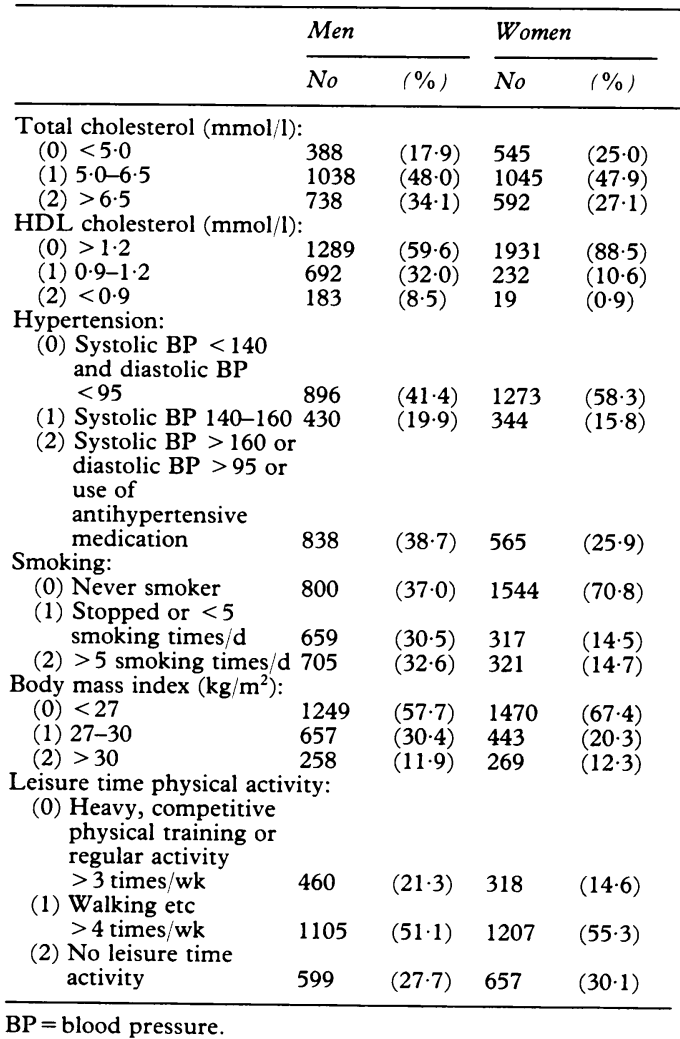

model that included age, area, and occupation increased the variance explained more among women $(+0.9)$ than among men $(+0 \cdot 1)$. Adjustment for marital status had little effect on the association between occupation and the cardiovascular risk factor score (fig 1, table 4(A) and (B)).

Education had a fairly linear association with the risk factor score in both sexes. In addition, the variance explained did not differ between men and women. Associations were as strong as in the analyses using occupation. Adjustment for other indicators made little difference to the observed associations (fig 2, table $4(\mathrm{~A})$ and (B)). When the model that included education as a categorical variable was compared with the model that included education as a continuous variable, the variation explained increased somewhat among women (from $2.9 \%$ to $3.1 \%$ ) but decreased among men (from $3 \cdot 3 \%$ to $2 \cdot 6 \%$ ).

Income also had a linear age adjusted association with the risk factor score, and the association was similar in both sexes (fig 3, table 4(A) and (B)). Income was inversely and significantly associated with the cardiovascular risk factor score in the age adjusted model in both sexes, but in the model with all socioeconomic indicators included, it was significant in women only. For both family income and education, risk factor scores were higher in

Table 4 Association of socioeconomic indicators with cardiovascular risk factor score in 2164 Finnish men and 2182 Finnish women aged 25-64 in 1987

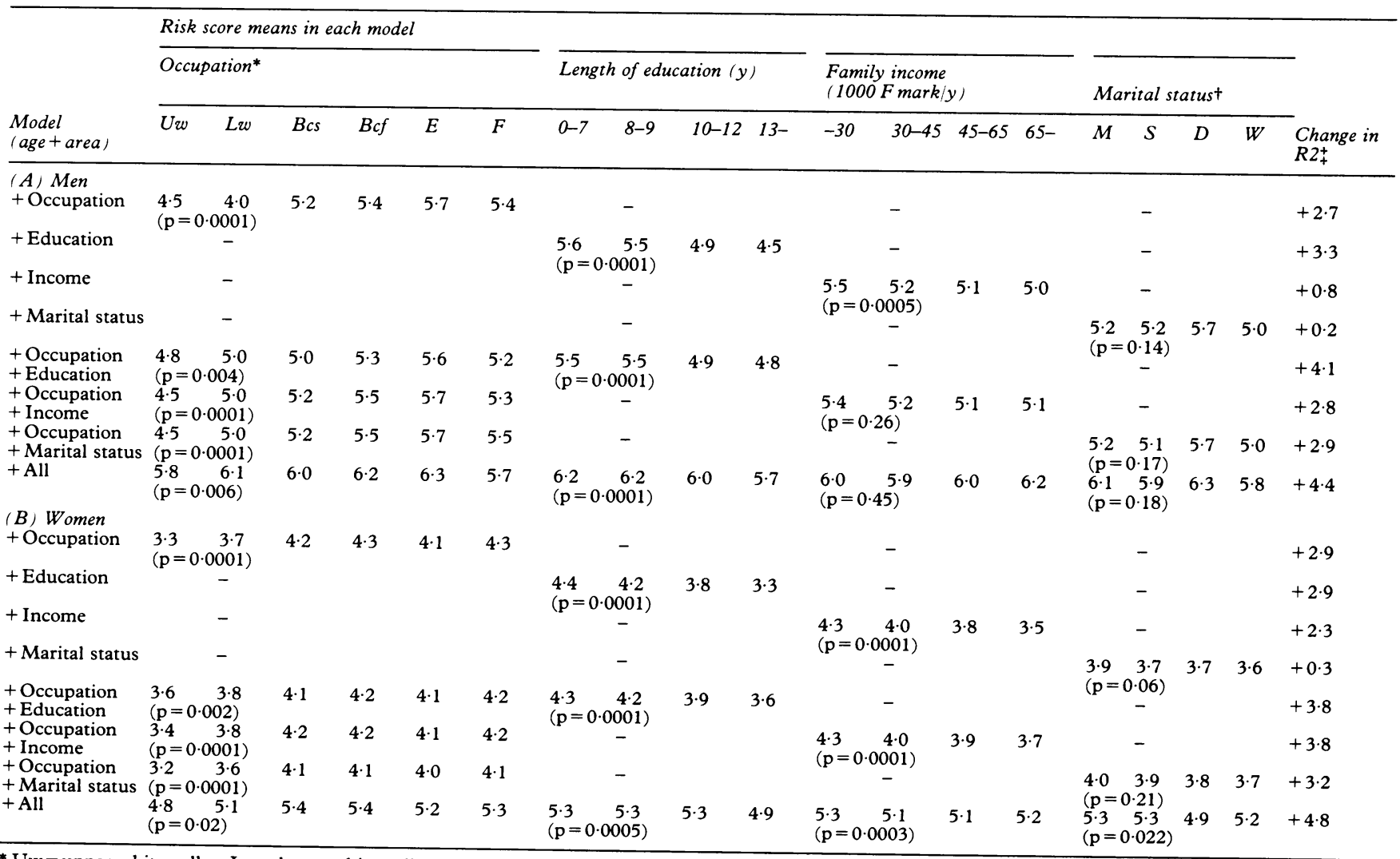

$* \mathrm{*}=$ upper white collar, $\mathrm{Lw}=$ lower white collar, $\mathrm{Bcs}=$ blue collar service workers, $\mathrm{Bcf}=$ blue collar factory workers, $\mathrm{E}=$ entrepreneurs, $\mathrm{F}=$ farmers .
$+\mathrm{M}=$ married, $S=$ single, $\mathrm{D}=$ divorced, $\mathrm{W}=$ widow, 


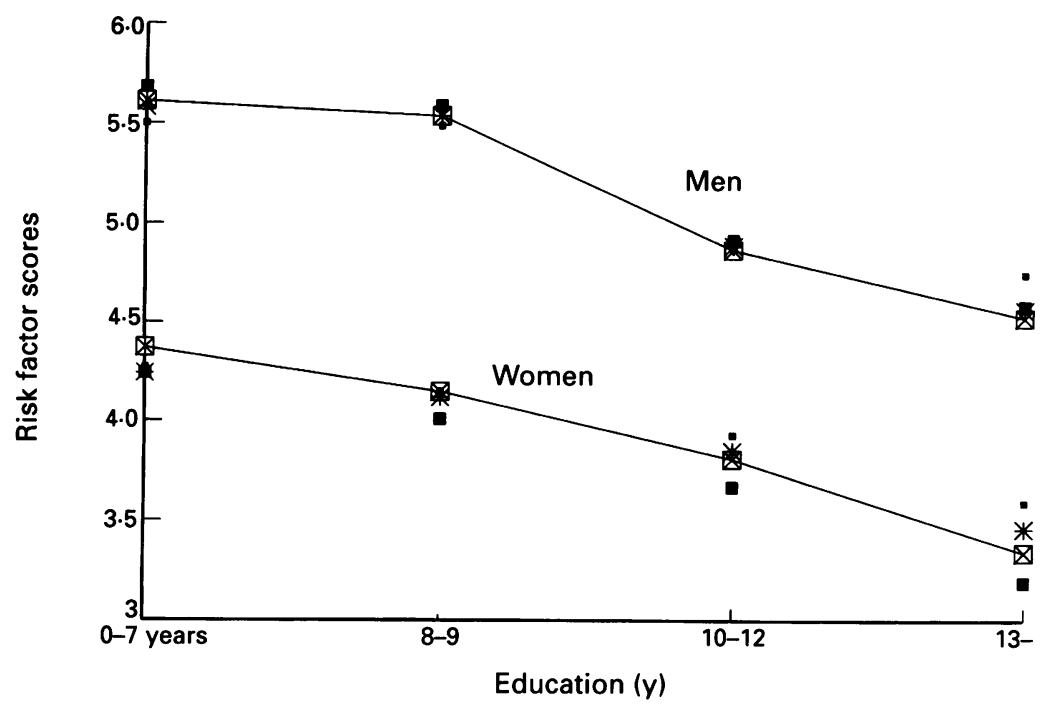

Figure 2 Least squares estimates of risk factor scores in relation to education from linear regression models for 2164 men and 2182 Finnish women from a population sample. Estimates from the basic model including age, area, and education, $(\otimes)$ on the solid line and estimates for models adjusted for family income (*), occupation ( $\mathbf{})$, or marital status ( $)$ at single points.

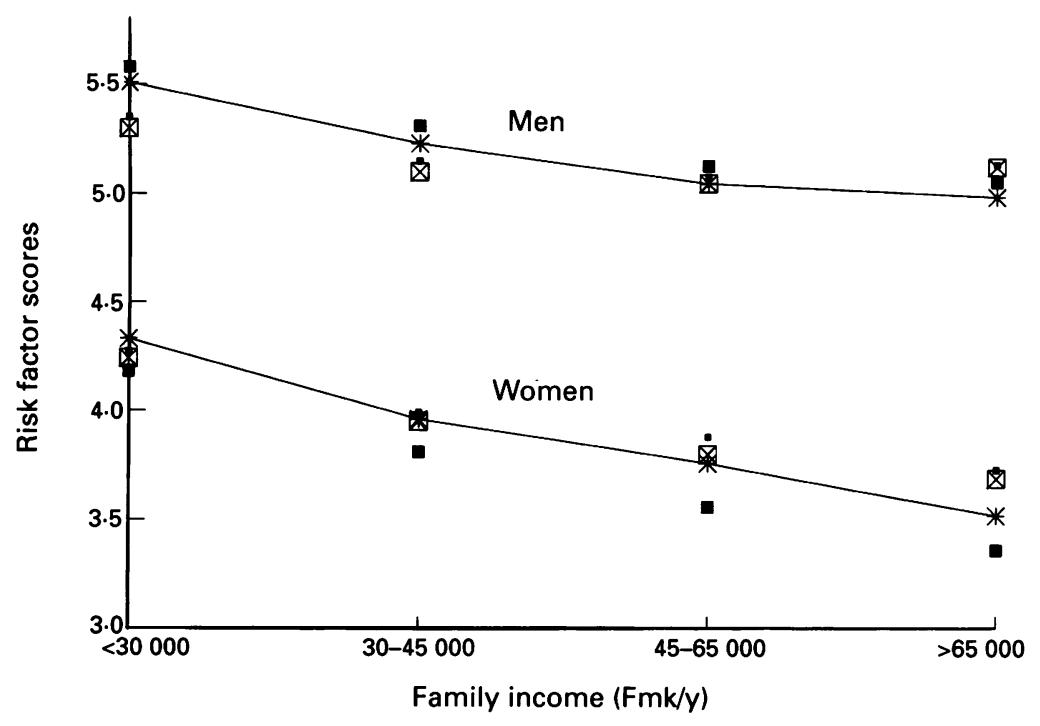

Figure 3 Least squares estimates of risk factor scores in relation to family income (Finnish marks/y) from linear regression models for 2164 men and 2182 Finnish women from a population sample. Estimates from the basic model including age, area, and family income, (*) on the solid line and estimates for models adjusted for education

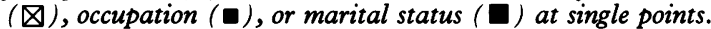

men, even in the highest socioeconomic classes, than in women in the lowest classes (fig 3).

Marital status was not a significant determinant of the cardiovascular risk factor score in men, but it was marginally significant in the age adjusted model in women (table $4(\mathrm{~A})$ and (B)). Divorced men had higher risk factor scores than divorced women, and married women had the highest risk factor scores.

\section{Discussion}

Of the socioeconomic indicators we studied, education and occupation had the strongest associations with levels of cardiovascular risk factors in middle-aged Finnish men and women. Income was the only socioeconomic factor that seemed to differentiate between men and women in respect of the estimated cardiovascular risk. Marital status was not related to the risk factors in men or women.

Analyses that compare associations of socioeconomic indicators with the cardiovascular risk factor score in men and women have not previously been undertaken. Studies of cardiovascular risk factors during the 1970s and the beginning of the 1980 s concentrated on men only, ${ }^{2134}$ or focussed on men and women in separate analyses..$^{3233}$

Previous studies comparing different socioeconomic indicators are also few. In the study by Abramson et al, ${ }^{30}$ patterns of associations with the health variables were similar for three different occupational indicators, education, and income. The three different occupational indicators were quite highly intercorrelated but less correlated to the other indicators. The authors argued that because of this, there are considerable advantages in using more than one indicator for socioeconomic status. Liberatos et $a l^{1}$ also concluded in their review that use of more than one socioeconomic indicator is preferable, because occupation and education may describe different aspects of socioeconomic position. Winkleby et $a l^{2024}$ studied the association between education and the cardiovascular risk factor score, adjusting for occupation and income. As in the present study, the association with education remained significant in both sexes after controlling for these two other indicators. ${ }^{24}$ House et $a l^{31}$ found that age, education, and income had highly significant associations with health measures such as morbidity or functional status. In their analysis, race, sex, and marital status had far smaller effects, which disappeared when adjusted for age, education, and income.

Risk factor score has been shown to be a good way to summarise the combined effects of different risk factors on future cardiovascular risk. ${ }^{150-212434-36}$ Risk factor scores usually include recognised biological factors such as the cholesterol concentrations (both total and HDL cholesterol), blood pressure, and body mass index, as well as behavioural variables such as cigarette smoking and leisure time activity. In some studies, food habits and stress have also been included in the score. ${ }^{37}$ To add different factors related to lifestyle such as leisure time activity and more biological risk factors such as cholesterol, is problematic. Different distributions of biological risk factors or health habits among women and men can, however, result in differences in the comparisons between men and women. In our data, as well as in previous studies, ${ }^{35}$ women had healthier lifestyles than men. A second reason using a risk factor score in the analyses instead of the separate risk factors was to keep the analyses manageable. All the risk factors we used to calculate the risk factor score are established predictors of cardiovascular risk. We have also shown previously that the main risk factors used in the risk factor score increase with lower levels of education in both men $^{38}$ and women. ${ }^{39}$ 


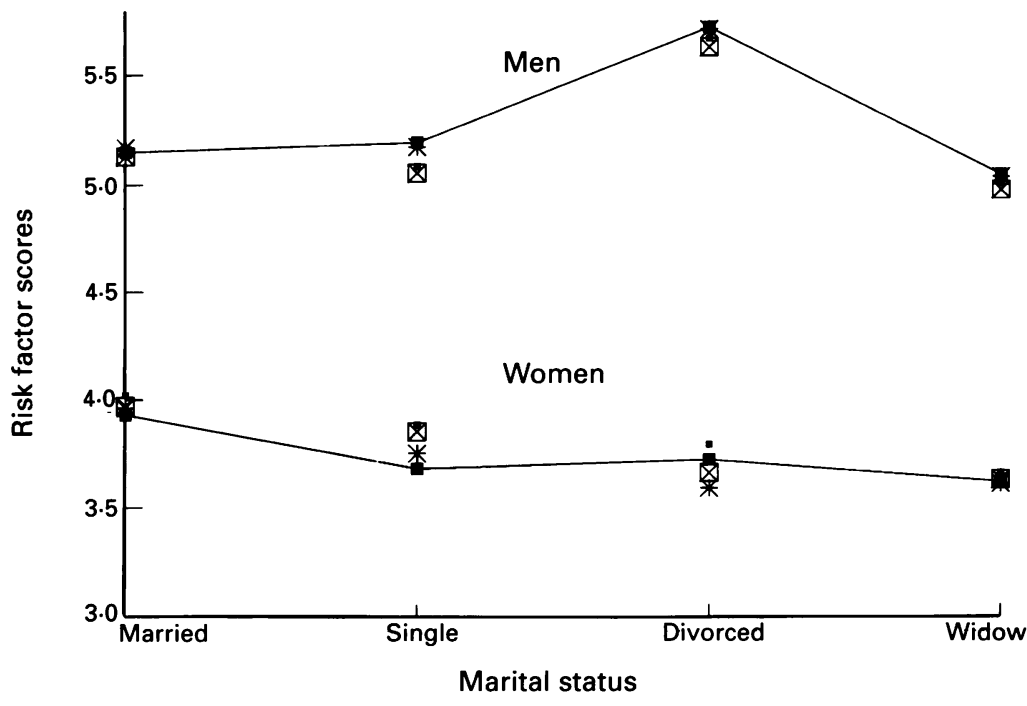

Figure 4 Least squares estimates of risk factor scores in relation to marital status from linear regression models for 2164 men and 2182 Finnish women from a population sample. Estimates from the basic model including age, area, and marital status, ( $)$ on the solid line. Least squares estimates for models adjusted for education ( $\bigotimes)$, occupation (घ), or income (*) at single points. dimension of socioeconomic indicators it is supposed to measure. If the indicators are used as continuous variables, such as years of education and family income, misclassification may be reduced, which should strengthen the observed association. In our data this was confirmed in the analysis on education in women. We used strength of association as a criterion for a good socioeconomic indicator. However, this is only one criterion and other approaches, such as gini-coefficients or slope indexes of inequality, do exist. ${ }^{40}$

Family income, measured cross sectionally, can recognise long term poverty, which is noted to be a more reliable indicator of poverty. ${ }^{142}$ Although such family income measurements are justifiable in their ability to identify possible poverty, occupation and, especially, education may be more accurate indicators. The difference between men and women in the importance of income as a socioeconomic indicator may be related to lifestyle differences. Another problem arises from using family income as a measure of income for a single person. That socioeconomic inequality between men and women can be hidden by using the family as a unit of analysis ${ }^{42}$ may also be true in our study.

It has been suggested that the use of a socioeconomic classification, originally based on male occupations, in classifying women dilutes the sex differences in health. ${ }^{43}$ In Finland, use of the woman's own occupation has been prevalent since the beginning of the 1970 s, unlike, for instance, in Great Britain, where the husband's occupation has been used instead. ${ }^{44}$ As approximately $10 \%$ only of Finnish women are classified according to their husband's socioeconomic status, the diluting effect is of minor importance in our study, and also in other Finnish studies.

Marital status was chosen as a socioeconomic indicator in our study as it was associated with risk factor levels in a previous study from the same areas. ${ }^{3}$ However, marital status, which we used more as a measure of social than economic status, was not significantly associated with the cardiovascular risk score in either sex. Previously, when women did not work outside the home so much, marital status was perhaps more of an economic measure. A suggestion that marital status has lost importance, especially with regard to other socioeconomic indicators, ${ }^{45}$ is supported by our results. The largest differences between the sexes have been suggested to prevail because of the different sets of social roles open to men and women. As marital roles are important to women, divorced women show poorer health than others. ${ }^{46}$ Our results suggest that this finding is even stronger in men. The fact that the association of occupation and education on cardiovascular risk factor scores is apparent among women may result from the synergistic effect of education and occupation on women's health. ${ }^{47}$

In conclusion, occupation is more likely to be associated with the most common health indicators, such as morbidity or mortality. Education reflects changes in socioeconomic situation much less effectively than occupation, because education is completed in an early phase of life. ${ }^{1}$ However, education is probably a more useful lem is the different degree of accuracy with which each indicator used really measures the 
indicator than occupation in all epidemiological studies which do not take changes in morbidity or mortality in a long timespan into account. Income is of more importance to women than has previously been suggested, perhaps because of the economic freedom it brings. Marital status is no longer useful as a socioeconomic indicator in epidemiological studies. In practice, occupation, education, and - if available for women - family income should be used as complementary indicators in studies concerning cardiovascular risk factors.

1 Liberatos P, Link BG, Kelsey JL. The measurement of social class in epidemiology. Epidemiol Rev 1988;10:87121.

2 Näyhä S. Social group and mortality in Finland. British fournal of Preventive and Social Medicine 1977;31:231-7.

3 Tuomilehto J, Puska P Virtamo J Nedicine 1977;31:231-7. $K$. Coronary risk factors and socioeconomic status in Eastern Finland. Prev Med 1978;7:539-49.

4 Salonen JT. Socioeconomic status and risk of cancer, cerebral stroke, and death due to coronary heart disease and any disease: a longitudinal study in eastern Finland. F Epidemiol Community Health 1982;36:294-7.

5 Salonen JT, Tuomilehto J, Nissinen A, Kaplan GA, Puska $P$. Contribution of risk factor changes to the decline in coronary incidence during the North Karelia project: a within-community analysis. Int $\mathcal{F}$ Epidemiol 1989;18:595601 .

6 Koskenvuo M, Kaprio J, Kesäniemi A. Sarna S. Differences in mortality from ischemic heart disease by marital status and soci

7 Koskenvuo M, Kaprio J, Lönnqvist J, Sarna S. Social factors and the gender difference in mortality. Soc Sci Med 1986;23:605-9.

8 Aro S, Räsänen L, Telama R. Social class and changes in health-related habits in Finland in 1973-1983. Scand $\mathcal{F}$ Soc Med 1986;14:39-47.

9 Rosengren A, Wedel H, Wilhelmsen L. Coronary heart disease and mortality in middle-aged men from differen occupational classes in Sweden. BM7 1988;297:1497-500.

10 Valkonen T, Martelin T, Rimpelä A. Inequity in the eyes of death. Socioeconomic mortality differentials in Finland 197185. Handbook no 172. (In Finnish with English summary.) Helsinki: Tilastokeskus, 1990

11 Lahelma E, Valkonen T. Health and social inequities in Finland and elsewhere. Soc Sci Med 1990;31:257-65.

12 Holme I, Helgeland A, Hjermann I, Leren P, Lund-Larsen PG. Four-year mortality by some socioeconomic indicators: the Oslo study. $f$ Epidemiol Community Health 1980;34:48-52.

13 Aromaa A, Reunanen A, Knekt P, Pyörälä K. Socioeconomic factors, risk factors for coronary artery disease. (In Fin nish.) In: Pyörälä K, Ahlström A, Pilli-Sihvola A-S, eds. Tutkimus ja kansanterveys 1980, part II: Sydän-ja verisuo nitautitutkimus ja ravitsemustutkimus. Helsinki, 1981:6683.

14 Dobson AJ, Gibberd RW, Leeder SR, O'Connell DL. Occupational differences in ischemic heart disease mortality and risk factors in Australia. Am $\mathcal{f}$ Epidemio 1985;122:283-90.

15 Smith GD, Shipley MJ, Rose G. Magnitude and causes of socioeconomic differentials in mortality: further evidence from the Whitehall study. I Epidemiol Community Health 1990;44:265-70.

16 Siegrist J, Bernhardt R, Feng Z, Schettler G. Socioeconomic differences in cardiovascular risk factors in China. Int $\mathscr{f}$ Epidemiol 1990;19:905-10.

17 Vartiainen E, Korhonen HJ, Pietinen P, Tuomilehto J, Kartovaara L, Nissinen A, Puska P. Fifteen-year trends in coronary risk factors in Finland, with special reference to North Carelia. Int $\mathcal{F}$ Epidemiol 1991;20:651-62.

18 Jones IG, Cameron D. Social class: an embarrassment to epidemiology? Community Med 1984;6:37-46.

19 Pearce NE, Davis PB, Smith AH, Foster FH. Mortality and social class in New Zealand. I: Overall male mortality. New Zealand Medical fournal 1983;96:281-5.

20 Winkleby MA, Jatulis DE, Frank E, Fortmann SP. Socio- economic status and health: how education, income and

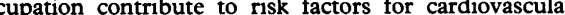
disease. Am f Public Health 1992;82:816-20.

21 Liu K, Cedres LB, Stamler J, et al. Relationship of education with major risk factors and death from coronary heart disease, cardiovascular diseases and all causes. Circulation 1982;66:1308-14.

22 Jacobsen BK, Thelle DS. Risk factors for coronary hear disease and level of education: The Tromso heart study. Am $\mathcal{F}$ Epidemiol 1988;127:923-32.

23 Doornbos G, Kromhout D. Educational level and mortality in a 32-year follow-up study of 18-year-old men in the Netherlands. Int $\mathcal{F}$ Epidemiol 1990;19:374-9.

24 Winkleby MA, Fortmann SP, Barrett DC. Social clas disparities in risk factors for disease: eight-year prevalence patterns by level of education. Prev Med 1990;19:1-12

25 Salomaa VV, Jauhiainen M, Pietinen P, Korhonen HJ Kartovaara L, Vartiainen E, Tuomilehto J. Five-year trend in serum HDL-lipoprotein cholesterol in the Finnish population aged 25-64 years. A suggestion of an increase. Atherosclerosis 1991;31:39-48.

26 Central Statistical Office of Finland. Classification of socioeconomic groups. Helsinki: Tilastokeskus, 1989. Handbook no 17 .

27 Study Group of the European Atherosclerosis Society. Strategies for the prevention of coronary heart disease; a policy statement of the European Atherosclerosis Society. Eur Heart $\mathcal{f} 1987 ; 8: 77-88$.

28 Report of a WHO Expert Committee. Arterial hypertension. Geneva: World Health Organization, 1978. Technical Report Series 628

29 SAS Institute. SAS user's guide. Version 5 edition. Cary, NC: SAS Institute Inc, 1985.

30 Abramson H, Gofin R, Habib J, Pridan H, Gofin J. Indicators of social class: a comparative appraisal of measures for use in epidemiological studies. Soc Sci Med 1982;16:173946.

31 House JS, Kessler RC, Herzog AR, Mero RP, Kinney AM, Breslow MJ. Age, socioeconomic status and health. Milbank $Q$ 1990;68:383-411.

32 Flegal KM, Harlan WR, Landis JR. Secular trends in body mass index and skinfold thickness with socioeconomic factors in young adult men. Am $\mathcal{f}$ Clin Nutr 1988;48:544 51.

33 Flegal KM, Harlan WR, Landis JR. Secular trends in body mass index and skinfold thickness with socioeconomic factors in young adult women. Am $\mathcal{F}$ Clin Nutr 1988 48:535-43.

34 Niknian M, Linnan LA, Lasater TM, Carleton RA. Use of population-based data to assess risk factor profiles of blu and white collar workers. F Occup Med 1991;33:29-36.

35 Shea $\mathrm{S}$, Stein $\mathrm{AD}$, Lantigua $\mathrm{R}$, et al. Independent associations of educational attainment and ethnicity with behavioral risk factors for cardiovascular disease. $A m$ Epidemiol 1991;134:567-82.

36 Kannel WB, McGee DL. Composite scoring-methods and predictive validity: insights from the Framingham study. predictive validity: insights from Res 1987;22:499-533.

37 Osler M, Lous J, Rasmussen NK. Knowledge, attitudes and cardiovascular risk factors in Danish adults. Scand $\mathcal{F}$ Soc Med 1992;20:151-7.

38 Pekkanen J, Uutela A, Kartovaara L, Tuomilehto J, Nissinen A. The education and cardiovascular risk factors of Finnish A. The education and cardiovascular risk factors of Finnish men in

39 Uutela A, Pekkanen J, Kartovaara L, Tuomilehto J, Nissinen A. Changes in cardiovascular risk factors among women in Eastern Finland 1972-87. (In Finnish.) Sosiaalilääk Aikak 1990;27:363-70.

40 Wagstaff A, Pierella P, Doorslaer E. On the measurement of inequalities in health. Soc Sci Med 1991;33:545-57.

41 Mincy RB, Sawhill IV, Wolf DA. The underclass: the definition and measurement. Science 1990;248:450-3.

42 Maynard $M$. The re-shaping of sociology: trends in the study of gender. Sociology 1990;24:219-90.

43 Arber S. Opening the 'black box': inequalities in women's health. In: Abbott P, Payne G, eds. New directions in the sociology of health. Brighton: Falmer Press, 1990.

44 Luoto R. Measurement of women's socioeconomic position a review. (In Finnish.) Sosiaalilääk Aikak 1991;28:159-65.

45 Abbott $\mathrm{P}$, Sapsford R. Women and social class. Guildford and Kings Lynn: Tavistock, 1987.

46 Arber S. Class, paid employment and family roles: making sense of structural disadvantage, gender and health status. Soc Sci Med 1991;32:425-36.

47 Gove WR. Gender differences in mental and physical illness: the effects of fixed roles and nurturant roles. Soc Sci Med 1984;19:77-91. 